\title{
The Impact of Job Nature on Job Involvement of the Teachers of Second grade of the Secondary School of $5^{\text {th }}$ District of Tehran
}

\author{
Peyman Pourmomen Davani \\ Department of Industrial Engineering, College of Technical and Engineering \\ South Tehran Branch, Islamic Azad University, Tehran, Iran \\ Email: pourmomen@yahoo.com
}

Received: June 14, 2016 Accepted: July 16, 2016 Published: July 28, 2016

doi:10.5296/ijld.v6i3.9793 URL: http://dx.doi.org/10.5296/ ijld.v6i3.9793

\begin{abstract}
The present study was conducted by the aim of investigating the impact of job nature on job involvement of teachers. The research method was of applied purpose and the data gathering method was descriptive survey. The population of the study included 650 teachers of second grade of the secondary school in $5^{\text {th }}$ district of Tehran, among which 242 individuals were selected as the sample through Jessie and Morgan table and stage cluster sampling. For gathering the data, job involvement questionnaire of Kanungo (1982) and the questionnaire of job nature based on Hackman and Oldham model (1980) were used. After collecting the questionnaires, investigation of the data and testing the hypotheses were done via structural equation modelling and by the help of SPSS PLS 2 in the measurement model and structural sections. In the first section, technical characteristics of the questionnaire, including reliability, convergent validity and divergent validity, specified to PLS were examined. In the second section, significance coefficients of the software were used to investigate the research hypotheses. Results confirmed the research hypotheses, that is, the effectiveness of job nature on its components on job involvement of the teachers.
\end{abstract}

Keywords: Job nature, Job involvement, Skill variety, Task nature 


\section{Introduction}

In today's organizations, the staff is expected to, in addition to having innovation and creativity, be involved and committed to their tasks, and in return, organizations should also provide decent and motivating working conditions for staff (Zacher, 2016). In one hand, the new approached, called positive organizational behavior that was developed in response to the changes in organizations, has offered some changes which are rooted in the expansion of using information and communication technology (ICT) and also rapid expansion of jobs in the service offering sections, using extra organizational sources and more flexible application of human resources (Pee and Chua, 2016). One of the important infrastructures of this approach is staff job involvement, which has been emerged in scientific, business, and organization psychology texts (Sohrabi Zadeh et al., 2012).

Shafley et al. (2008) defined job involvement as a positive and job-related state of mind which is determined by energy, dedication and job attraction. The job involved staff have so much energy and they have sufficient enthusiasm to do their job tasks. They are so drowned in and concentrated on their job that they don't notice the passage of time (Heidari Nejad and Moradi, 2011).

Efficacy and effectiveness of organizations is affected by various factors, one of which is staff job involvement. In organizations, Individuals have different attitudes which affect their behavior in organization. Among these attitudes, this has not been a long time that the term "job involvement" has entered into organizational behavior. Interest and positive attitude towards the job leads to more job effort, and consequently to reducing the costs (Heidari Nejad and Moradi, p 6). Mahdad (2010), defines job involvement as the intensity of psychological identification of the person with his/her job. Also, most theorists has suggested that the staff with so much job-involvement, put a fundamental and obvious effort towards their personal goals and tasks, and they are less likely to leave their job (Yousef Zadeh et al., 2011, p 111).

Venikissa (2008) emphasizes that there is a significant correlation between management factors and job involvement so that, the job-involved individuals tend to make strong emotional bonds with the organization, and this leads to this fact that they are less likely to think of leaving the organization than other individuals (Halberg and Shaghley, 2008, quoted from Yousef Zadeh et al., 2011, p 112). The findings of Strömgren, Eriksson, Bergman \& Dellve (2016) also suggested that there is a positive association between the learning of goal-oriented staff with internal motivation and job involvement.

Jung and Yoon (2016) believe that job involvement has important impacts on job outputs such as job performance, organizational citizenship behavior and absence from work. In this regard, Jung and Yoon (2015), in their research, showed that attitude variables such as commitment and involvement have important impacts on job performance and organizational citizenship behavior. Robbins, also, (1999) proposed job involvement as one of the most important indices of working life quality. On the other hand, Brown (2007) believes that job involvement is partly the result of personality, individual characteristics, the organizational environment, job design, and supervision behavior. Therefore, It can be said that one of the 
effective factors in staff job involvement is their job nature on job characteristics.

Primary studies related to job nature on characteristics were the studies conducted by Trend and Laurence (1965). For the purpose of assessing the staff reaction to various jobs, they conducted large projects. In their belief, prefer complex and hard-labor jobs to monotonous and boring jobs, and also, job complexity leads to satisfaction and presence of the staff (Zhao, Ghiselli Law \& Ma, 2016).

In 1980, Hackman with the cooperation of Oldham, introduces job characteristics theory; main dimensions of this theory are: skill variety, job nature, the importance of the job, autonomy or independence, feedback from job (Zhao, Ghiselli Law \& Ma, 2016). The jobs daily done by people are both a foundation for organization design and a clear manifestation of the organizations' structures (Robbins, 2009, p 299). Based on these studies, Hackman and Oldham found that those staff, whose job was high in internal dimensions, felt greater satisfaction and motivation that those staff whose job was low in internal dimension (Bakhtiar Nasr Abadi et al., 2009, p 61). The job characteristic model also determines the main 5 dimensions of job, their mutual relations, and their impact on productivity, motivation and satisfaction of staff (Robbins, p 302).

In a research, Cam (2008) showed that organizations reduce job fatigue and difficulty among their staff by providing autonomy and feedback during the work, and therefore, they lead to staff satisfaction (Bakhtiar Nasr Abadi et al., 2009, p 62). Carion et al. (2003), also, in their research in IT enterprise on gender, job type, and job characteristics, found that job characteristics and organization characteristics have more impact on job satisfaction and job effort of women.

Job involvement is a positive and job-related state of mind which is determined by energy, dedication and job attraction, and also job nature and characteristics of each person in the organization is open to review and reflection. Since job attitudes can act as one of the effective factors in forming job behaviors, many researches have attempted to investigate positive attitude and job involvement and also the factors effective on job nature and characteristics.

Due to unfavorable conditions, such as inadequate salary and benefits, many teachers in public schools are attracted to private schools, and they have no interest in continuing their work in public schools, and the continuation of this trend will lead to severe lack of qualified teachers in public schools. Findings indicate that job involvement of staff, improvement, renewal and providing school equipment are among the problems of public schools.

As, in schools, the nature and quality of service provision to students is much related to teachers performance, we intend to answer the questions addressing the relationship between job characteristics and the level of job involvement. Finally, in the present research we aim to explain the impact of job nature on job involvement of the teachers serving in the second grade of secondary level in $5^{\text {th }}$ district of Tehran.

According to the above question, the research hypotheses are: 
- Job nature affects job involvement of teachers serving in the second grade of secondary level in $5^{\text {th }}$ district of Tehran.

- Skill variety affects job involvement of teachers serving in the second grade of secondary level in $5^{\text {th }}$ district of Tehran.

- Task meaningfulness affects job involvement of teachers serving in the second grade of secondary level in $5^{\text {th }}$ district of Tehran.

- Task importance affects job involvement of teachers serving in the second grade of secondary level in $5^{\text {th }}$ district of Tehran.

- Autonomy and independence affects job involvement of teachers serving in the second grade of secondary level in $5^{\text {th }}$ district of Tehran.

- Performance feedback affects job involvement of teachers serving in the second grade of secondary level in $5^{\text {th }}$ district of Tehran.

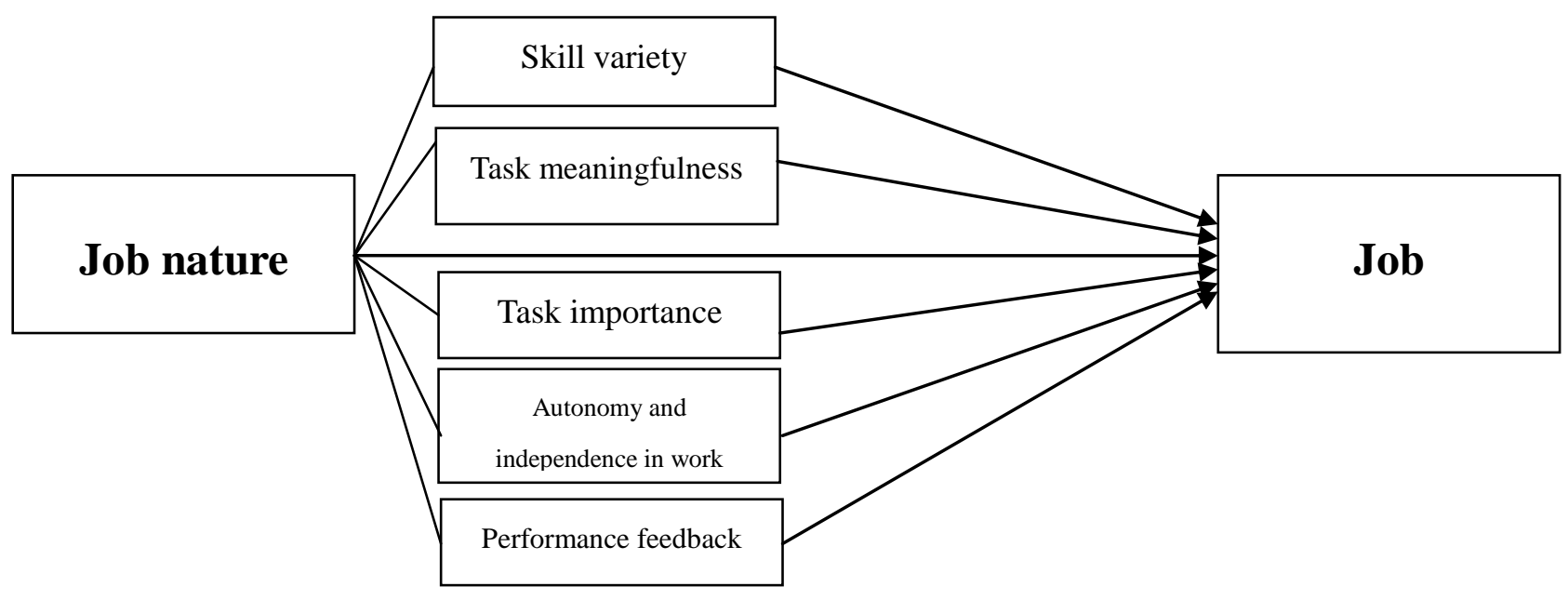

Figure 1. Conceptual model of Cango (1982) and Hackman and Oldham's (1980) research

\section{Methodology}

Since the present research was intended to investigate the effect of job nature on teachers' job involvement, and the applications of the data results, thus, the aim was of applied type and the data gathering method was descriptive survey. The population of the research included 650 teachers of the second grade of secondary level in $5^{\text {th }}$ district of Tehran, among which 242 individuals were selected as the sample through Jessie and Morgan table and stage cluster sampling method.

The data gathering instrument of the present study included two standardized questionnaires, with 50 questions. For assessing involvement, the Cango (1982) questionnaire is used, which is designed on a 5 -point scale (from $1=$ strongly disagree to $5=$ strongly agree). Also, 18 researched-made questions which were adopted from Hackman and Oldham's (1980) theories about job nature, with a 5-point Likert scale has been designed and are used to assess job nature. This questionnaire includes these dimensions: skill variety, meaningfulness of task, 
task importance, the variety of independence and autonomy in work and performance feedback.

In the present research, for the purpose of determining the validity of the questionnaires, content validity and construct validity were used. For examining content validity, the questionnaires were affirmed by the advisor professors and the experts of this domain, and the necessary modifications were considered.

For construct validity, also, structural equation modeling and the Smart PLS software were used. Construct validity is divided into convergent validity and divergent validity. For the convergent validity, the AVE (Average Variance Extracted) criterion was used, and the results for the research variables was gained to be 0.5 that showed the convergent validity of the instrument. Also, the matrix for calculating divergent validity showed that the divergent validity is affirmed. Also, for calculating reliability, Cronbach's alpha coefficient and combined reliability coefficient were used, and the results showed the reliability of the instrument, because in both indices the coefficient was higher than 0.7. Results of the psychometric properties of the instrument for the research variables are shown in the table below:

Table 1: Results of psychometric properties for research variables

\begin{tabular}{|c|c|c|c|c|c|}
\hline $\begin{array}{l}\text { dimensio } \\
\text { n }\end{array}$ & Variable & Reference & alpha & AVE & CR \\
\hline \multirow{5}{*}{$\begin{array}{l}\text { Job } \\
\text { nature }\end{array}$} & Skill variety & \multirow{5}{*}{$\begin{array}{l}\text { Hackman and } \\
\text { Oldham (1980) }\end{array}$} & 0.76 & 0.66 & 0.81 \\
\hline & Task nature & & 0.91 & 0.62 & 0.90 \\
\hline & Meaningfulness & & 0.72 & 0.83 & 0.82 \\
\hline & independence & & 0.71 & 0.62 & 0.76 \\
\hline & feedback & & 0.76 & 0.73 & 0.82 \\
\hline \multicolumn{2}{|c|}{ Job involvement } & Cango (1982) & 0.74 & 0.57 & 0.76 \\
\hline
\end{tabular}

Analyzing the data gained for the questionnaires, using PLS software in the framework of structural equation modeling was analyzed in the inferential section.

\section{Findings}

In this stage, the cause and effect relationship of job nature and its components with job involvement of the teachers form second grade of secondary schools of $5^{\text {th }}$ district of Tehran has been assessed in the frame of the structural equation section. As observed in the figure below, the impact of job characteristics and its components on empowering the teachers of second grade of secondary schools in $5^{\text {th }}$ district of Tehran is significant and positive. In the 
following figure, the path coefficients for research hypotheses are shown.

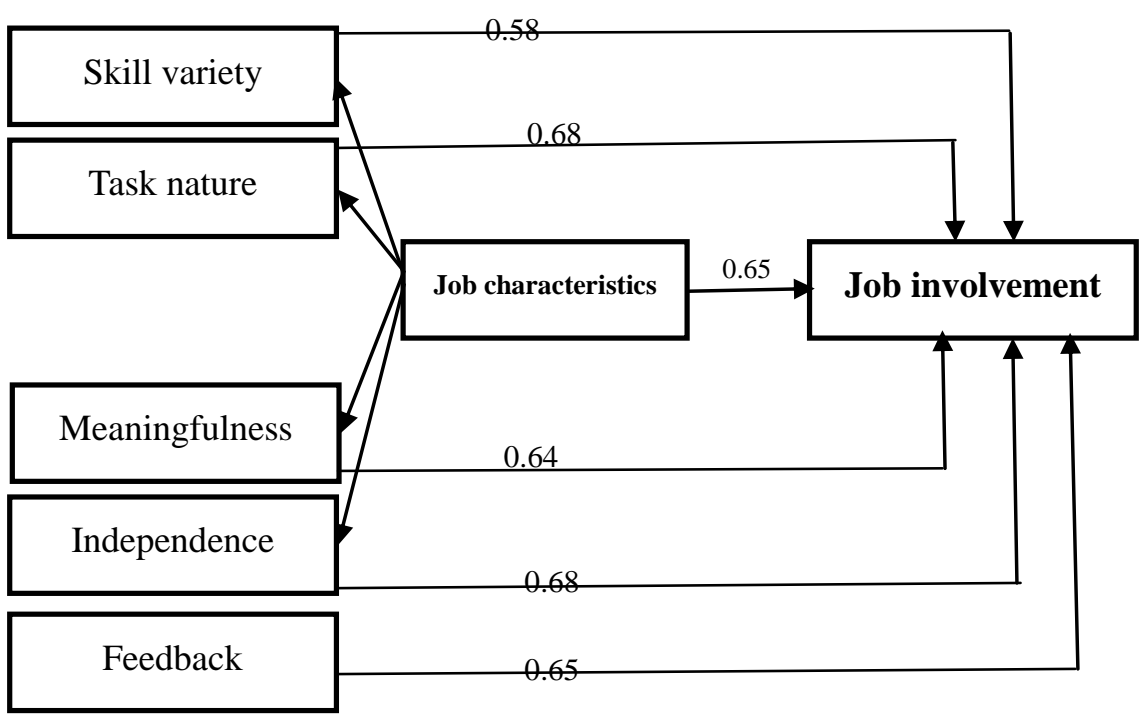

Fig 2: the causal impact coefficients of the research model

In the above figure, the causal impact coefficient of the research model and the impact of the main dimension (job nature) and its components on job involvement of second grade teachers of secondary schools in Tehran is shown. The PLS output confirms the main hypothesis and also secondary hypotheses of the research which is shown the table below; since all the $t$-values are higher than 1.96 , all the hypotheses are confirmed.

Table 2: examining Research Hypotheses

\begin{tabular}{|l|l|l|l|}
\hline Hypotheses & $\begin{array}{l}\text { Standardized } \\
\text { coefficients }\end{array}$ & t-value & Result \\
\hline $\begin{array}{l}\text { Job nature } \rightarrow \text { job involvement of second grade } \\
\text { teachers of secondary schools in } 5^{\text {th }} \text { district of Tehran }\end{array}$ & 0.65 & 17.03 & Approved \\
\hline $\begin{array}{l}\text { Skill variety } \rightarrow \text { job involvement of second grade } \\
\text { teachers of secondary schools in } 5^{\text {th }} \text { district of Tehran }\end{array}$ & 0.58 & 17.63 & Approved \\
\hline $\begin{array}{l}\text { Task nature } \rightarrow \text { job involvement of second grade } \\
\text { teachers of secondary schools in } 5^{\text {th }} \text { district of Tehran }\end{array}$ & 0.68 & 16.54 & Approved \\
\hline $\begin{array}{l}\text { Meaningfulness } \rightarrow \text { job involvement of second grade } \\
\text { teachers of secondary schools in } 5^{\text {th }} \text { district of Tehran }\end{array}$ & 0.64 & 17.30 & Approved \\
\hline $\begin{array}{l}\text { Independence } \rightarrow \text { job involvement of second grade } \\
\text { teachers of secondary schools in } 5^{\text {th }} \text { district of Tehran }\end{array}$ & 0.68 & 17.84 & Approved \\
\hline
\end{tabular}


Feedback $\rightarrow$ job involvement of second grade teachers of secondary schools in $5^{\text {th }}$ district of Tehran

\section{Conclusion and Recommendation}

In this part, first a summary of the research findings is presented, and then, according to the literature and the results of data analysis, recommendations are offered in this area. The results of research hypotheses are interpreted in this part, according to the gathered data from statistical tests in chapter 4. Findings suggested that job nature and its components impact job involvement of second grade teachers of secondary schools in $5^{\text {th }}$ district of Tehran.

It can be said that, the higher skill variety, job nature, job value, independence-seeking, and job feedback of the staff is, the greater their motivation, enthusiasm and job involvement would be. Also, it has been shown in different researches that, when working in jobs which are full of variety, when feeling more responsibility and value, and when having more authority, the staff receive better feedback, have more satisfaction, and therefore have job involvement and get more motivation to continue their work. Therefore, managers can consider job nature as one of the important factors affecting job involvement and put more emphasis on it.

The requirement of the job for doing different and various activities, shows skill variety. It can be claimed that if a job requires doing activities with different skills and talents, then, that job would be considered as having meaningful involvement, and not only creates a feeling of satisfaction and non-monotony, but also creates a feeling of involvement and motivation for the job in the person. In addition, research has indicated that moderate job variety is more effective. Extensive variety leads to ambiguity and stress, and on the other hand low variety leads to monotony and boredom that consequently causes job dissatisfaction. Ambiguity in role and conflict in role has been always avoided by staff. Because if staff are not familiar with the work they do and with the expectations, their dissatisfaction will result.

When job responsibilities are determined in such a way that they are clear for the staff from beginning to the end, and the person has a complete picture of his/her job tasks and considers him/herself as part of the work, then this would lead to the fact that other staff also would have more satisfaction towards their job, their job motivation would increase due to their job involvement, and finally the effectiveness and efficiency of the organization will raise.

If the understanding of the staff about the importance and effect of their work on the life and work of others outside and inside the organization increases, their job involvement also would increase due to the importance and value if their job. Job values is a mentally that person seeks for the purpose of satisfying his/her needs so that he/she can get job satisfaction. In addition, job values direct personal motivations, and this in turn, impacts the profession selection, career development, and job adjustment (Yazdi and Hosseinian, 2005).

Those managers are more successful that, in applying principles of authority delegation, pay enough attention to the abilities and talents of their subordinates and by involving them in the organization's affairs, directs the good performance of human resource tasks towards higher 
goals. Because one of the most important managerial tools, that gives life and mobility to the organization and its goals and causes the staff to have more job involvement, is giving authorities to them, that must be based on organizational structure and infrastructure, goals, assignment and professionality. Managers, in authority delegation, should solve every ambiguity in assigning the tasks and enhance the motivation of the subordinates.

In performance feedback, it is considered that if the job is designed in such a way that clear and straight information is offered to the staff about the effectiveness of the results or their job performance or not. Meanwhile, by creating feedback in the organization, we would witness improvements in behaviors and higher motivation of the organization's staff, and by creating a better feedback condition, the awareness level of the individuals in relation to the effectiveness of their job performance would increase, and individuals would feel more satisfaction, and consequently, their commitment, job involvement and also organization involvement would raise.

Results of the researches conducted by Lou et al. (2007), Rous et al. (2006), Carion et al. (2003), Bakhtiar Nasr Abadi et al. (2009) and Vakili et al. (2009) are good confirmations for the present hypothesis, that each of them, consistent with affirming the above discussions, found that job nature and characteristics are related to satisfaction from the work, motivation, and job involvement of the staff.

According to the research findings, the following recommendations are offered:

- For increasing the variety of teachers' skills, tasks can be combined, i.e., school principals should intend to integrate major and minor works and create a new collection of tasks that are extended and expanded.

- Teachers should consider their job as having a clear beginning and end, i.e., they should have a clear understanding of their job.

- Teachers should feel that their job has a great impact on life or job of other people.

- By holding training courses regarding major job and organizational values, the opportunity for knowing these issues should be provided for the teachers.

- Delegation of authority to teachers, should be considered in some of the school decision-makings.

- Teachers should immediately and concurrently with their work become aware of their performance result.

\section{References}

Bakhtiar Nasr Abadi, H., Rajaee Pour, S., Salimi, Gh.A., Taher Pour, F. and Partovi, M. (2009). Study of the relationship between work nature and occupational satisfaction, Journal of Administrative Management, Y. 9, Issue 1, pp. 57-75.

Heidari Nejad, S. and Moradipour, M. (2011). The relationship between job attachment of physical education teachers and organizational climate in high school in Ahwaz, Journal of 
Sport Management, Issue 8, pp. 33-46.

Robins, S. (2009). Organizational Behavior: Concepts, Theories and Suggestions. Translated by: Parsaian, A. and Erabi, M., $6^{\text {th }}$ Ed., Tehran, State Management Training Center Publication.

Sohrabi Zadeh, S., Keshtkaran, A. and Kawousi, Z. (2012). Job attachment and factors affecting it among nurses in public training hospitals in Shiraz University of Medical Sciences, Journal of Tehran University of Medical Sciences, Vol. 6, Issue 2.

Vakili, N., Golparvar, M. and Atashpour, H. (2009). The role of transformational leadership job features and difficulty of goal in performance of employees in SEPAHAN Steel Company, Journal of Research and Knowledge in Applied Psychology, Issue 39, pp. 1-22.

Yazdi, S.M. and Hosseinian, S. (2005). Comparison of job values among women and men with academic education prior to entrance to job market, Journal of New Educational Thoughts, Issue 1, pp. 63-76.

Yusefizadeh, S., Mahdad, A. and Mehrizadegan, I. (2011). Comparison between organizational commitment, job attachment and job performance among university faculty members, Journal of New Findings in Psychology, Y. 5, Issue 20, pp. 35-48.

Brown, Steven P. (2007) .Job involvement. Encyclopedia of Industrial and Organizational Psychology, Volume 1. Thusand Oaks: Sage Publications .pp397-399

Carayon, P, Honokker, P, Marchlands, S and Schwarz. J. (2003) Job characteristic and quality of working life in the IT workforce. The role of gender. Acm siecff / sigmis Conference.

Jung, H. S., \& Yoon, H. H. (2015). Understanding pay satisfaction: The impacts of pay satisfaction on employees' job engagement and withdrawal in deluxe hotel. International Journal of Hospitality Management, 48, 22-26.

Jung, H. S., \& Yoon, H. H. (2016). What does work meaning to hospitality employees? The effects of meaningful work on employees' organizational commitment: The mediating role of job engagement. International Journal of Hospitality Management, 53, 59-68.

Kanungo, R. N. (1982). Measurement of job and work involvement. Journal of applied psychology, 67(3), 341.

Oldham, G. R., \& Hackman, J. R. (2010). Not what it was and not what it will be: The future of job design research. Journal of organizational behavior, 31(2-3), 463-479.

Pee, L. G., \& Chua, A. Y. K. (2015). Duration, frequency, and diversity of knowledge contribution: Differential effects of job characteristics. Information \& Management.

Robbins, S. P., \&Coutler, M. (1999).Management.Upper Saddle River, NJ: Prentice hailInternational.Inc.

Rose, R. C., Beh, L., Uli, J., \& Idris, K. (2006). An analysis of quality of work life (QWL) and career-related variables. American Journal of Applied Sciences, 3(12), 2151. 


\section{Macrothink}

International Journal of Learning and Development

ISSN 2164-4063 2016, Vol. 6, No. 3

Strömgren, M., Eriksson, A., Bergman, D., \& Dellve, L. (2016). Social capital among healthcare professionals: A prospective study of its importance for job satisfaction, work engagement and engagement in clinical improvements. International journal of nursing studies, 53, 116-125.

Zacher, H. (2016). Within-person -relationships between daily individual and job characteristics and daily manifestations of career adaptability. Journal of Vocational Behavior, 92, 105-115.

Zhao, X. R., Ghiselli, R., Law, R., \& Ma, J. (2016). Motivating frontline employees: Role of job characteristics in work and life satisfaction. Journal of Hospitality and Tourism Management, 27, 27-38.

\section{Copyright Disclaimer}

Copyright for this article is retained by the author(s), with first publication rights granted to the journal.

This is an open-access article distributed under the terms and conditions of the Creative Commons Attribution license (http://creativecommons.org/licenses/by/3.0/). 